bachelor's degree in education from Bridgewater State College, a master's in Latin American History from New York University, and an MLS from Columbia University. He was an active member of the Seminar on the Acquisition of Latin American Library Materials (SALALM), and edited A Bibliography of Latin American Bibliographies: Social Sciences and Humanities.

Fred B. OXTOBY, former descriptive cataloger at the Library of Congress, died January 1 in Washington. Oxtoby retired from his position at the Library of Congress in 1981 after 14 years of service. Prior to his service at LC, he was chief of the Cata- log Department at the John Crerar Library, Chicago. Oxtoby's previous professional posts included work as head cataloger at the Illinois Institute of Technology and as a cataloger at the University of Illinois. He earned a bachelor's and master's in library science from the University of Illinois.

Mary L. WoODWORTH, assistant director of the University of Wisconsin-Madison School of Library and Information Studies, died suddenly March 2 in Madison. Woodworth had been a faculty member at UW since 1964 and had received a bachelor's and a master's degree there.

\title{
CLS directions
}

\author{
By Jean Pelletiere \\ Chair, ACRL College Libraries Section
}

\section{Real income, comparable worth, and other activities of the College Libraries Section.}

H professional with a master's degree, who was familiar with a variety of information retrieval systems-including computer-based data banks... who could supervise a large staff, develop and implement a budget, and actively market the service-and handle building maintenance problems? Sound like a high five-figure job? How about $\$ 15,000$ ?" The Christian Science Monitor asked this question last year in an article about librarians' new skills.

The $\$ 15,000$ figure hurts. It is typical for college librarians. Even if each entering librarian were independently wealthy it still would hurt. The comparably low pay still would devalue our work in relation to others.

An instructor with me at Berkeley, Lois Harzfeld, pointed out the Library Journal interviews in which most librarians would not have minded leaving the field, and the New Republic article on real income for different occupations (librarians were second from the bottom, just above welfare recipients). "Why doesn't any library organization address that problem?" she asked.

My first chance to address that problem is now. The question of real income is close to comparable worth, in that some occupations generate more real income for doing less work. Also, the status of librarians as faculty members is close to that of comparable worth, in that librarians and classroom professors are of comparable worth in the college setting, and thus should be comparably treated.

Comparably, not equally. When librarians are treated equally with classroom faculty, the things we do as they do them are judged by their standards, while the things we do as we do them are judged by their standards. The result is that, as one 


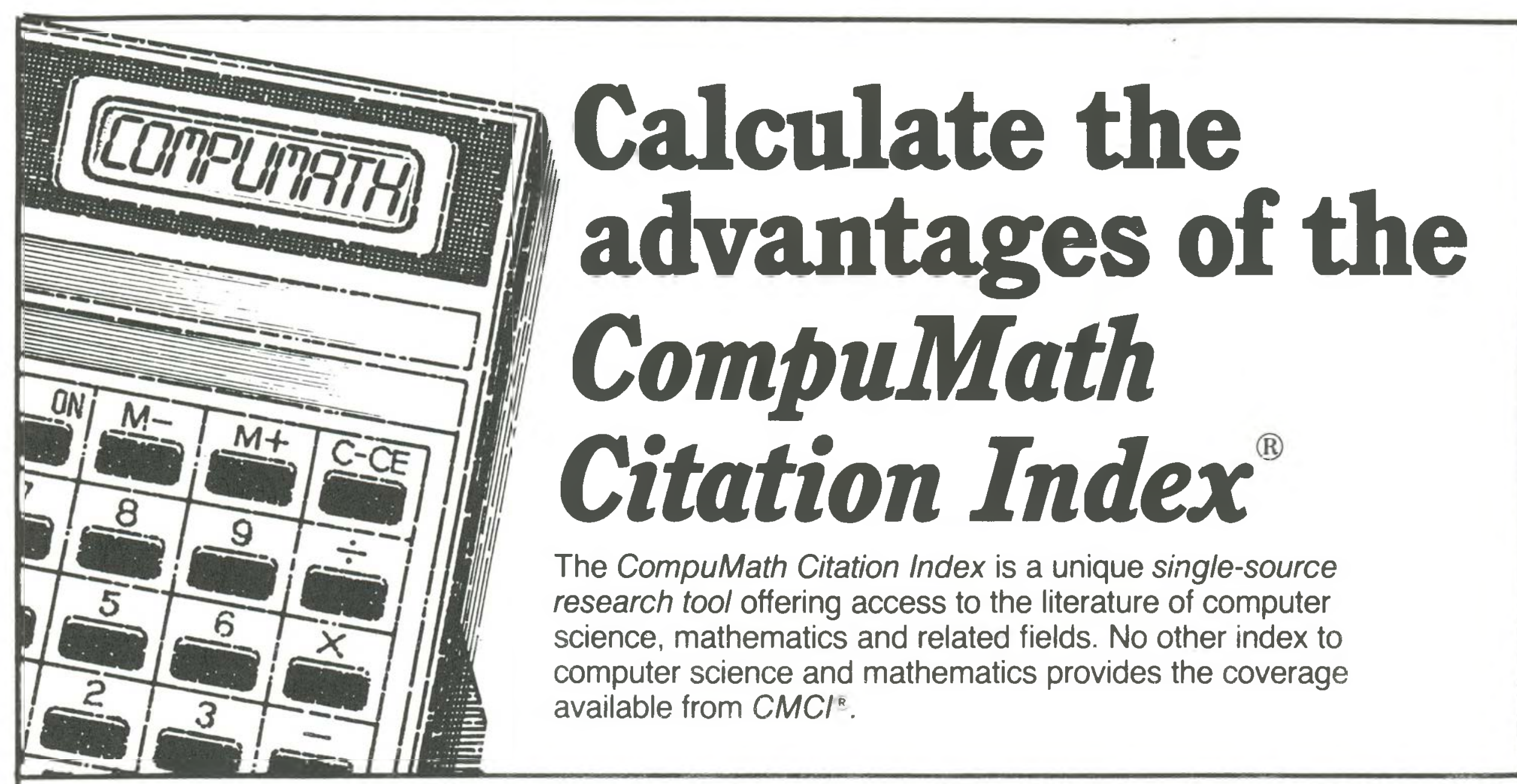

You can count on CMCI to offer you these important advantages:

円In-Depth Coverage

$\mathrm{CMCl}$ provides full coverage of the world's leading computer science, mathematics and statistical journals-plus selective coverage of over 6,000 journals in the sciences, social sciences, and arts and humanities.

\section{$\boxplus$ Unique Multidisciplinary}

\section{Coverage}

$\mathrm{CMCl}$ provides full or selective coverage of many of the journals indexed by Science Citation Index ${ }^{\mathrm{R}}$, Social Sciences Citation Index ${ }^{\mathrm{R}}$, Arts \& Humanities Citation Index ${ }^{\text {is }}$ and Current Contents ${ }^{\mathrm{R}}$.

This means that $\mathrm{CMCl}$ pulls together applications in medicine, chemistry, business, education and hundreds of other areas-so you don't have to subscribe to thousands of journals to retrieve complete information on the latest applications in any field.

\section{田 Up-To-Date Information}

$\mathrm{CMCl}$ is published in two softcover issues and an annual hard. bound cumulation. Each triannual contains current year journal information-making $\mathrm{CMCl}$ the most up-to-date computer science and mathematics index available.

\section{$\boxplus$ Searching Versatility}

$\mathrm{CMCl}$ enables you to retrieve information through a variety of access points: author name, title word, cited reference, author affiliation and research front specialty. No matter how specific your search-or how fragmentary the information you have to initiate it- $\mathrm{CMCl}$ will provide the information you need.

\section{$\boxplus$ Critical Reviews}

As of $1985, \mathrm{CMCl}$ indexes computer hardware, software and database critical reviews-so you and your patrons can keep up with new computer technologies being applied and reported today.

\section{$\boxplus$ Citation Indexing}

CMCl's Citation Index groups together all current items referencing the same earlier work, making the earlier work an indexing term useful in retrieving current papers on the same subject-enabling you to obtain information you might have missed with other search methods.

Together, these advantages make $\mathrm{CMCl}$ a valuable addition to your library. To receive a FREE copy of the most recent triannual or to arrange the loan of a three-volume hardbound annual (at no obligation), write us at the address below ... or call us toll-free 800 523-1850, extension 1371

The CompuMath Citation Index. Its advantages really add up.

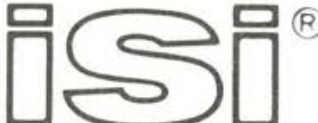

\section{Institute for Scientific Information ${ }^{\circledR}$}

Customer Services Department, 3501 Market Street, Philadelphia, PA 19104 U.S.A. Telephone: (215)386-0100, ext. 1371, Cable: SCINFO, Telex: 84-5305

European Office: 132 High Street, Uxbridge, Middlesex UB8 1DP, United Kingdom Telephone: 44-895-70016, Telex: 933693 UKISI 


\section{What's news at UMI?}

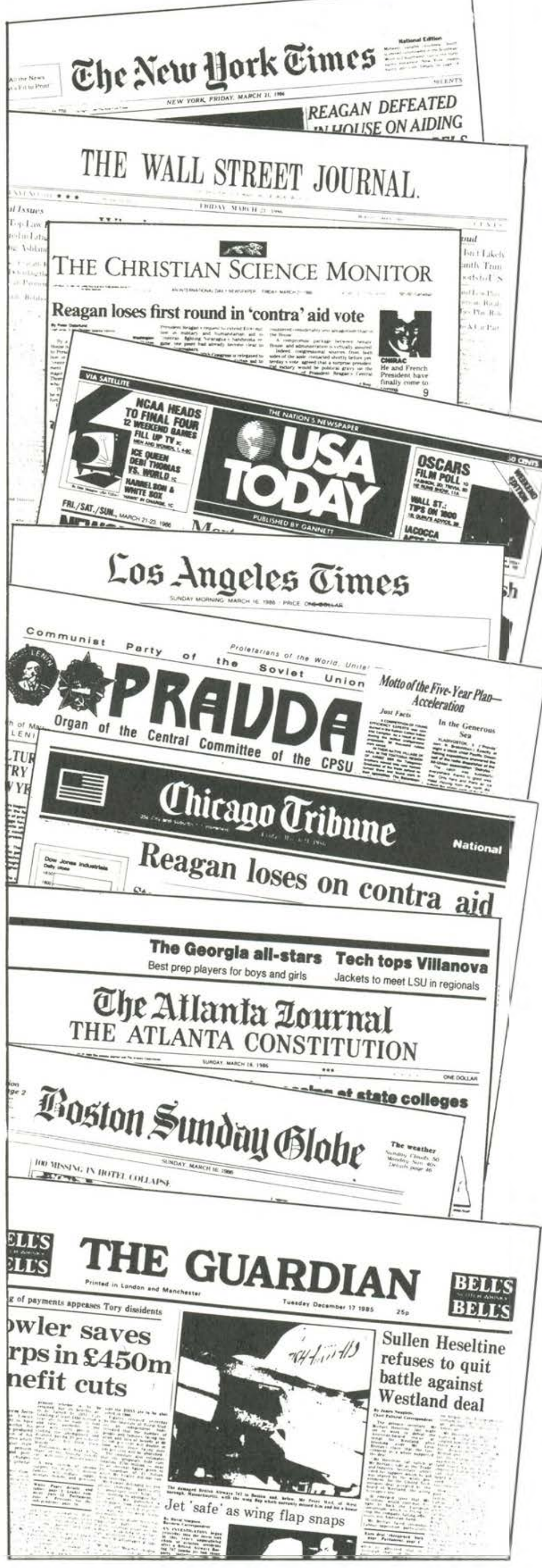

7,000 newspapers in microform... and a new subscription bonus!

D ouble your microform-buying dollars - and increase your patrons' access to the newswith the Spring Newspaper Subscription Bonus from University Microfilms International (UMI).

Here's how it works: Just purchase a new 1986 subscription to any newspaper in microform and/or newspaper index we offer, and receive:

- The 1985 year of the same title free, or

- "Bonus dollars" in an amount equal to the price of your new 1986 subscription!

If you choose the "bonus dollars," you can use them to obtain microform hardware, backfiles (of newspapers, indexes, and/or periodicals), or additional newspaper and index subscriptions. Make your subscription selections from our extensive collection of nearly 7,000 newspapers.

Choose from international titles like the English-language version of Pravda and Britain's Guardian. U.S. titles like The New York Times, The Wall Street Journal, USA Today, and The Christian Science Monitor. Plus numerous major metropolitan, regional, and local newspapers from across the country and more than 20 comprehensive indexes.

To take advantage of this special offer - which expires July 15, 1986 - you'll need both of our 1986 catalogs: Newspapers in Microform and More Newspapers in Microform. Order them by calling us toll-free at 1-800-521-3044. From Alaska, Hawaii, or Michigan, call collect (313) 761-4700. Canadian customers call toll-free 1-800-343-5299. Or use the convenient coupon below. We'll send them immediately, along with more detailed information about our bonus offer.

Please send me the Newspapers in Microform and More Newspapers in Microform catalogs.

$\square$ Please send me more information about the Spring Newspaper Subscription Bonus.

Name

Title

Company/Institution

Address

$\overline{\text { City }}$

State

Telephone

Place this coupon in an envelope and mail it to: University Microfilms International, Attn: Serials Marketing Department, 300 North Zeeb Road, Ann Arbor, Michigan 48106.

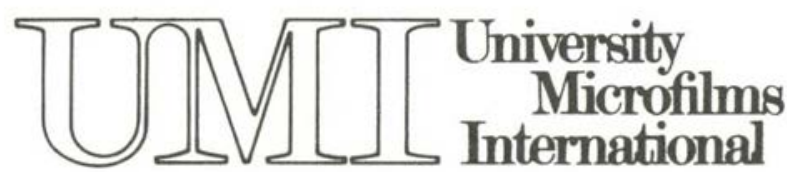


letter in American Libraries recently pointed out, most things we do in a 40-hour work week they do not consider up to their standards, nor up for their rewards.

Thus I have proposed, and the CLS Executive Committee has approved, an ad hoc CLS Real Income Committee for a three-year term with the following charge: to gather income studies from states, systems, and companies, and spell out what these might mean for college librarians; and to work closely with the ALA Commission on Pay Equity in drafting national programs to be translated into a campaign for use in higher education associations and in colleges themselves - with the strength of ALA behind them.

If you are interested in working on this committee, contact: Susan Stussy (chair), Director of the Library, Marian College, 3200 Cold Spring Road, Indianapolis, IN 46222. William Delzell and Wendell Barbour are also members.

A second ad hoc committee I proposed, and the Executive Committee approved, is the CLS Historical Commission (a name selected by its members) with Susan Campbell as chair. Its charge is to prepare a history of the College Libraries Section, to collect and suggest procedures, and to assemble them into a section manual. The Commission, also with a three-year life, includes Betty Corbett, Michael Haeuser, and Michael La Croix.

Arising out of the idea of the CLS Historical Commission is the new CLS Bylaws Committee. The bylaws were revised in 1981 and 1982 but were never made official; thus the 1974 version is still in use. We need to bring them into line with new ALA and ACRL bylaws, as well as smooth the sometimes awkward procedures with which we are now operating. I welcome volunteers and nominations for this committee.

The increase in vitality of CLS portends expansion of its services to members. It offers a chance for librarians who want to influence the section's direction. These committees embody several interests evidenced by the CLS Advisory Council.

Action Item 1. Contact me if you would like to start another committee, and give me the reasons why. I can propose committees to the Executive Committee at ALA Annual Conference.

Action Item 2. Contact me if you would like to be on the agenda with any matter concerning college librarians at the CLS annual membership meeting.-Jean C. Pelletiere, Rockefeller Research Scholar, College of Public Affairs and Policy, SUNY Albany, 135 Western Avenue, Albany, NY 12222; (518) 370-4124.

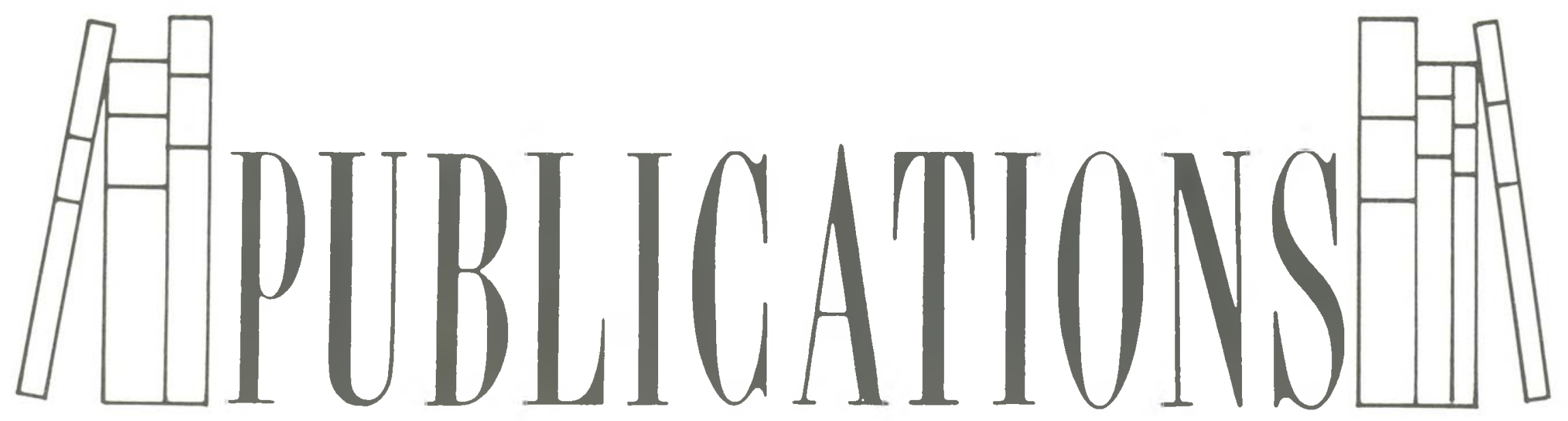

- Bibliographic Instruction in ARL Libraries, SPEC Kit \#121 (107 pages, February 1986), examines current developments and anticipated trends based on a survey of 25 ARL libraries with active BI programs. It identifies the use of new technology in BI programs and the expansion of programs to reach more diverse audiences as two important trends. BI planning materials for seven libraries are provided in the kit, along with three examples of CAI programs and microcomputer-based instruction, two descriptions of graduate student instruction, and one description of international student instruction. SPEC kits are available by subscription from the SPEC Center, ARL/OMS, 1527 New Hampshire Ave., N.W., Washington, DC 20036. Individual issues cost $\$ 20$ each, prepayment required.

- End-User Searching Services, SPEC Kit \#122 (112 pages, March 1986), presents the results of a survey of ARL libraries on their methods of assisting students and faculty with database searching.
The kit includes one grant proposal, five program descriptions, four examples of publicity, nine sets of instructional aids and reference tools, six evaluation/questionnaires, and a select bibliography. See previous entry for cost and address.

- Essential Guide to CD-ROM, edited by Judith Paris Roth (189 pages, March 1986), provides information on the basic concepts and principles of optical Compact Disc Read-Only Memory (CDROM) technology, as well as its hardware and software, and specific applications. One section of the book covers the prototype CD-ROM library and information systems developed by Brodart, Faxon, Ingram, and Newsbank. A CD-ROM disc containing over 8800 programs with documentation from the IBM PC SIG Library of Public Domain and User-Supported software accompanies the book, which sells for \$29.95 from Meckler Publishing Corporation, 11 Ferry Lane West, Westport, CT 06880-5808. ISBN 0-88736-045-9.

- Female Psychology: A Partially Annotated Bib- 